\title{
ACADEMY OF SOIENCES
}

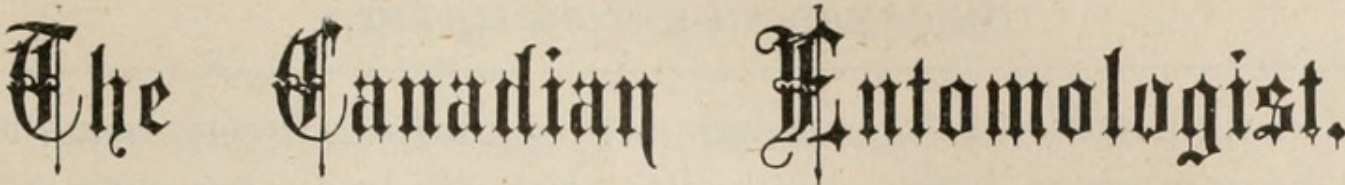

Vol. XLVI.

LONDON, APRIL, 1914

No. 4

\section{A SYNOPSIS OF THE GENERA IN CHLOROPIDA, FOR NORTH AMERICA.}

J. R. MALLOCH, URBANA, ILLINOIS.

Having had occasion recently to identify species of North America Chloropidæ, I found some difficulty in placing the specimens in their proper genera by the use of the published keys to the family. The most recent paper on the Chloropidæ is that by Becker,* which is a rather unsatisfactory one, lacking in many details, though it purports to be a "monographic" treatise. About a dozen North American species are left out of the paper, and the table of genera in the Chloropinæ is so framed that it is not possible to locate specimens generically. I do not purpose criticising Becker's work, believing that criticism alone is seldom beneficial, and offer the following table, which I hope will prove useful to the extent of satisfactorily locating specimens in the genera to which they belong.

I have to thank Dr. S. A. Forbes for permission to publish this paper

Generic Synopsis :

1. Costa reaching to third vein or slightly beyond it ........2 Costa reaching distinctly to fourth vein

2. Outer cross-vein absent. Elliponeura Loew.

Outer cross-vein present. .3

3. Hind femur much thickened, hind tibia bent........... 4

Hind femur not thickened; hind tibia straight, or almost so . . .5

4. Third joint of antennæ much elongated, about four times as long as broad; veins 2 and 3 but slightly bent forward............................

Third joint of antennæ but little longer than broad; veins 2 and 3 much bent forward..............Meromyza Meigen.

*Ann. Nat. Mus. Hung., 1912. 
5. Mid tibia with the apical spur strong and distinctly bent; male hypopygium large, knob-like, curved back beneath abdomen Cetema Hendel.

Mid tibial spur short and straight; male hypopygium not conspicuous .

6. Scutellum flattened on disk, with a distinct marginal rim, the apical scutellar bristles closely approximated; both sexes with an elongated oval, flattened surface (sensory organ) on hind tibia (postero-dorsal surface)....... Chloropisca Loew.

Scutellum convex, not margined, apical bristles not approximated.

7. Sensory organ present on hind tibia, as in

Chloropisca.

Pseudochlorops, n. gen.

Sensory organ absent from hind tibia ............ 8

8. Head very distinctly produced in front; ocellar triangle very broad at vertex, carried forward to above antennæ in a broad prolongation, the centre convex, the sides of frons more or less excavated; third joint of antennæ distinctly longer than broad; arista generally appearing flattened through the presence of thick pubescence.

Ectecephala Macquart.

Head only slightly, or not at all, produced in front; frontal triangle triangular, or subtriangular, flat; sides of frons more or less excavated . . . . . . . . . . . . . . . 9

9. Cross-veins strongly approximated; veins 2 and 3 bent forward.

Diplotoxa Loew.

Cross-veins not approximated; veins 2 and 3 almost straight.

10. Third antennal joint disc-like; head not produced anteriorly; mesonotum yellow, with black or red stripes, seldom black, and indistinctly punctured or unpunctured

Chlorops Meigen.

Third antennal joint longer than broad, head at least slightly produced anteriorly; or mesonotum black and strongly punctured . . . . . . . . . . . . . . . . . 11

11. Mesonotum entirely black, coarsely

punctured.

Epichlorops Becker. 
Mesonotum not strongly punctured, and with distinct stripes.

12. Head produced anteriorly; third joint of antenna at least $11 / 4$ times as long at base

*Parectecephala Becker. Head not distinctly produced; third joint of antenna but little longer than broad; dull yellow and black, robust species, with black palpi. *Anthracophaga Loew.

13. Hind tibia with a distinct, curved, apical thorn on the anterior

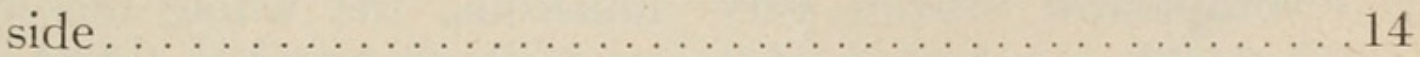

Hind tibia without such thorn $\ldots \ldots \ldots \ldots \ldots \ldots \ldots \ldots$

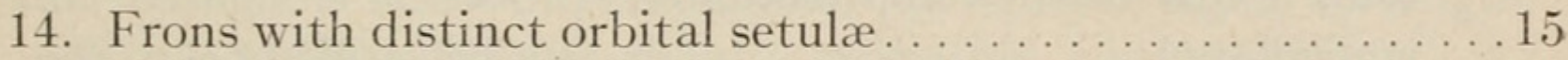

Orbits with, at most, weak hairs .

15. Scutellum elongated, disk flattened; male proboscis with two long apical hairs................ Prohippelates Malloch.

Scutellum not elongated, convex; male proboscis normal...................Pseudohippelates Malloch.

16. Arista flattened, strap-like.......... Ceratobarys Coquillett. Arista not flattened . . . . . . . . . . . . . Hippelates Loew .

17. Second vein exceptionally short, third costal division much longer than second............. Siphunculina Rondani.

Second vein not shortened, third costal as long as, or shorter, than second . . . . . . . . . . . . . . . . . 18

18. Arista either broadened and strap-like, or with distinct pubescence. . . . . . . . . . . . . . . . . . . . . . 19

Arista neither thickened nor distinctly pubescent........22

19. Arista more or less distinctly flattened, the pubescence very close, giving the arista a knife-like appearance even when the arista itself is but slightly flattened . . . . . . . . . . 20

Arista normal in shape, pubescence rather loose . . . . . . . 21

20. Scutellum subtriangular, the marginal bristles situated on small warts.................. Crassista von Roser.

Scutellum rounded in outline, the margin without

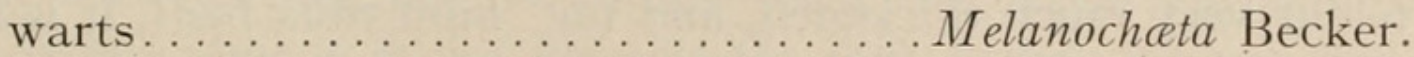

21. Scutellum elongated, the disk flattened .......... Gaurax Loew

*The line of demarcation between these genera is very unsatisfactory, and though I am rather inclined to reject Parecteiephgla as entitled to gene1 ic rank, I have not sufficient material before me to enable me to decide the matter satisfactori'y. 
Scutellum rounded, convex.................

22. More than two bristles present on posterior part of notapleura . . . . . . . . . . . . . . . . . 23

Only two bristles on posterior part of notapleura . . . . . . . 24

23. Generally four notapleural bristles present; mesonotum with a row of bristles on or near to posterior margin; scutellum with about eight marginal bristles; proboscis not elongated.....................Eugaurax Malloch.

Notapleural bristles very numerous, the whole mesonotum thickly setulose; scutellum subtriangular, disc thickly setulose, apical bristles approximated; proboscis elongated and geniculated.

Chactochlorops, n. gen.

24. Outer cross-vein absent.................. Dicraus Loew.

Outer cross-vein present. . . . . . . . . . . . . . 25

25. Proboscis elongated and geniculated, mouth margin slightly produced and with a hair-like bristle at vibrissal angle. Madiza Fallen.

Proboscis fleshy, very slightly or not at all elongated, vibrissal hair absent.

26. Mesonotum with three distinct longitudinal sulci.

Mesonotum not sulcate. Tricomba Liog. Botanobia Liog.

From an examination of the material contained in several collections, and the descriptions by many previous authors, I find that in many cases species are placed in wrong genera, and purpose at some future time publishing notes in addition to those presented herewith as a guide to those who may have occasion to identify specimens belonging to this family.

\section{Notes AND Descriptions:}

Neodiplotoxa, n. gen.

This genus I have erected for the reception of Diplotoxa nigricans Loew. Owing to the fact that this species has the hind femur very much thickened, and the hind tibia bent, it is impossible to locate it except in Meromyza by the use of the older keys to the genera. It differs, however, very considerably from Meromyza in the structure of the antenna.

Type: Diplotoxa nigricans Loew. 


\section{Meromyza flavipalpis, n. sp.}

Similar in coloration to pratorum var. americana Fitch, the palpi being entirely yellow. It differs from that species as indicated below :

Length of lower cheek margin barely equal to height of anterior profile of head, and barely two-thirds as long as height of head at vertex; face distinctly retreating in profile flavipalpis, n. sp.

Length of lower cheek margin about $1 \frac{1}{2}$ times height of anterior profile of head, and slightly more than equal to height of head at vertex; face but slightly retreating, concave in centre pratorum Fallice.

In addition to the above flavipalpis is considerably larger than pratorum, $4.5-5 \mathrm{~mm}$. as against $2.5-3.5 \mathrm{~mm}$.

Locality of specimens of flavipalpis: Champaign, Illinois, June 22, 1888, two males (Marten and Hart).

Type: Illinois State Lab. Nat. Hist. collection.

\section{Chloropisca Loew.}

There is present on the postero-dorsal surface of the hind tibia in the species belonging to this genus an elongate oval, flattened area, which occupies about two-thirds of the length of the tibia. This area is slightly depressed and thickly covered with closely set, short hairs, which leads me to consider that this area is the seat of some sensory organ. I have examined examples of the following genera and find that this organ is present in varying extent in: Chloropisca, Pseudochlorops, Crassiseta, Melanochreta, and Botanobia, and absent in the species I have examined in Elliponeura, Ectecephala, Meromyza, Neodiplotoxa, Diplotoxa, Chlorops, and Epichlorops.

The amount of material available to me at present is not such that I can form any distinct idea of the significance of this organ in the classification, nor do I know what the organ may have as its function; but it is not improbable that it may prove of considerable value in classifying this rather closely allied group. It appears rather strange to me that Chloropisca, which has very much the general habitus of, and is very similar in food habits to Chlorops, should have this organ well developed, whereas the latter 
genus so far as I have discovered, should not possess the organ. Possibly the examination of more material, and living examples, may throw more light upon this matter.

\section{Chloropisca obtusa, n. sp.}

Female shining yellow. Frontal triangle glossy, brownish black; basal joints of antennæ brown, upper margin of third joint blackened, the lower part yellow; face and cheeks yellow; proboscis palpi, and clypeus yellow; arista brown, yellow at base. Mesonotum with the three glossy black stripes very broad, the area between them suffused with black, giving the disk the appearance of being entirely black, the narrow black stripes before wing base separated from the sub-dorsal stripes except anteriorly; mesopleura with a small black spot; the mark on sternopleura reddish yellow, scutellum yellow; postnotum glossy black. Abdomen with a . broad, black, foremarginal band on each segment. Legs yellow: apical three joints of fore tarsi and apical joint of other tarsi blackened; sensory organ not differing from colour of hind tibia. Wings clear, veins brown, last section of fourth vein less distinct than the other veins. Halteres whitish yellow.

Frontal triangle occupying about three-fourths the width of frons at vertex, carried forward of almost equal width for almost two-thirds the length of frons, then gradually tapering to just above antennæ, the apical third leaf like, the sides slightly convex, surface unpunctured, smooth; third joint of antennæ about $1 \frac{1}{4}$ times as long as broad; arista about as long as width of frons at anterior margin; face slightly receding; cheek about one-fifth as high as eye; eye distinctly, but not greatly, higher than long. Scutellum distinctly broader than long, not so noticeably subtriangular as in glabra Meigen, the apical bristles present. Legs slender, the fore tarsi not thickened; sensory organ occupying about three-fifths the length of the hind tibia. Wing with discal cell narrow, inner cross-vein well before end of first vein; penultimate section of fourth vein distinctly longer than basal section of third, longer than last section of fifth and about half as long as last section of fourth.

Length: $3.5 \mathrm{~mm}$. 
Locality: Champaign, Illinois, "swept from amongst grass a 1 weeds," May 30, 1889 (Marten).

Type: Illinois State Lab. Nat. Hist. collection.

This species may be separated from any previously described form by the obtuse frontal triangle. It is most closely allied ts glabra Meigen.

Chloropisca glabra, var. clypeata, n. var.

This variety may be separated from the type form its by being larger, $3 \mathrm{~mm}$., in having the third antennal joint $1 \frac{1}{4}$ times as lo. as broad, the clypeus yellow, instead of black as in glabra, and the sternopleura without the black spot.

Localities: Algonquin, Illinois, September 21, 1894 (W. A. Nason), Urbana, Illinois, swept from catalpa, June 21, 1883 (Marten); Urbana, Illinois, July 15, 1887, in woods (C. A. Hart).

This form may really be a distinct species, but colour alone is not a reliable guide to the separation of species in this genus, an 1 till I see more material, I consider it best to give the form varietal rank only.

\section{Pseudochlorops, n. gen.}

The type species of this.genus is Chlorops unicolor Loew. It differs from Chlorops in having a distinct sensory area on the hin 1 tibia, and from Chloropisca in having the scutellum convex.

\section{Prohippelates Malloch (Pr. U. S. N. M., 1913).}

The type of this genus is Hippelates pallidus Loew. This genus and its allies, Hippelates, Pseudohippelates and Ceratobarys, have been dealt with in a paper which I have now in the press.

\section{Pseudohippelates Malloch (Pr. U. S. N. M., 1413).}

The type of this genus is Pseudohippelates capax Coquillett.

Siphunculina Rondani.

To this genus belongs Siphonella reticulata Loew.

Neogaurax, n. gen.

The type of this genus is Gaurax montanus Coquillett. It differs, as indicated, in the foregoing table, from Gaurax in the. 
shape of the scutellum and is more closely allied to Botanobia than to Gaurax, differing from it principally in the distinctly pubescent arista.

Chaetochlorops, n. gen.

The type of this genus is Siphonella inizilina Coquillett. The characters given in the foregoing table should suffice for its identification. This is the only species I know which is referable to this genus.

The other changes in generic names I have already dealt with in the Canadian Entomologist, 1913, p. 175.

\section{A PHALANGID DRINKS MILK.}

I generally have a cup of milk placed in my room, which I drink after I have finished my nocturnal rounds of my treacled trees.

The other night I saw a very fine specimen of a Harvestman (Phalangid) in the saucer. Wondering what brought him there, I managed to remove the cup without disturbing him, and found that a small quantity of milk had been spilt into the saucer and that the spider was taking a drink.

He first anchored his fourth pair of legs on the rim of the saucer; then gradually-very slowly-lowered his body till it was nearly touching the liquid. It was then tipped forward and downwards, until the mouth was in contact with the milk. After about a minute he raised himself to his ordinary standing height and began to clean his mouth, opening and shutting his mandibles (or whatever they are) like a pair of compasses. I was surprised at their size - far larger and more formidable looking than one expects from the size of the creature. Then he raised one or other of his second pair of legs and used the claw to finish the cleaning process. This done to his satisfaction he took another drink. This he did three successive times, and then, satisfied I suppose, took his departure. I noticed he was most careful to keep his feet out of milk.-E. Firmstone Heath,

The Hermitage, near Cartwright, Man.

September 6th, 1913. 


\section{$2 \mathrm{BHL}$ Biodiversity Heritage Library}

1914. "A synopsis of the genera in Chloropidae, for North America." The Canadian entomologist 46, 113-120. https://doi.org/10.4039/Ent46113-4.

View This Item Online: https://www.biodiversitylibrary.org/item/22201

DOI: https://doi.org/10.4039/Ent46113-4

Permalink: https://www.biodiversitylibrary.org/partpdf/6951

\section{Holding Institution}

MBLWHOI Library

\section{Sponsored by}

MBLWHOI Library

\section{Copyright \& Reuse}

Copyright Status: NOT_IN_COPYRIGHT

This document was created from content at the Biodiversity Heritage Library, the world's largest open access digital library for biodiversity literature and archives. Visit BHL at https://www.biodiversitylibrary.org. 